Situs Jurnal : $\underline{\text { http://ejournal.stiepancasetia.ac.id/index.php/jieb }}$

Jilid 6 Nomor 2 Juli 2020

Hal $210-217$

\title{
ANALISIS AKUNTANSI PIUTANG USAHA TERHADAP LAPORAN KEUANGAN CV. LINGGAR PERDANA BANJARMASIN
}

\section{Irwan Shabirin Putra*}

Abstrak : Penelitian ini bertujuan untuk mengetahui akuntansi piutang usaha terhadap laporan keuangan CV. Linggar Perdana Banjarmasin selama ini dan yang seharusnya. Metode penelitian ini menggunakan deskriptif kualitatif yang bertujuan yang memecahkan masalahnya dengan menggunakan data dan bahan empiris. Hasil penelitian dapat disimpulkan bahwa perlakuan akuntansi piutang usaha yang diterapkan CV. Linggar Perdana Banjarmasin tidak mengacu pada SAK yang mengharuskan penyajian piutang sebesar jumlah bruto dikurangi taksiran jumlah yang tidak dapat diterima. Akibatnya, laporan yang disusun perusahaan tidak mencerminkan keadaan keuangan dan hasil usaha seharusnya. CV. Linggar Perdana Banjarmasin seharusnya menggunakan metode cadangan dalam menyusun laporan keuangan perusahaan yang sesuai dengan SAK untuk memprediksi besarnya jumlah piutang yang tak tertagih yang akan diakui sebagai kerugian piutang perusahaan.

Kata Kunci : Perlakuan, Penilaian, Pelaporan Piutang 


\section{Latar Belakang}

Piutang merupakan bagian aktiva lancar yang relatif aktif dalam suatu perusahaan guna membantu kelancaran kegiatan perusahaan, untuk itu maka penerapan akuntansi piutang yang baik dan relevan sangat diperlukan agar memberikan dampak terhadap laporan keuangan sesuai prinsip kehati-hatian atau konservatisme, sehingga perusahaan diharapkan dapat menyajikan laporan keuangan secara wajar serta berpedoman dengan teori yang mengacu pada konsep akuntansi yang berlaku khususnya yang berhubungan dengan masalah piutang usaha.

Piutang merupakan tagihan perusahaan kepada pihak lain yang nantinya akan dimintakan pembayarannya, jika sudah sampai waktu pembayarannya. Seharusnya tagihan tersebut harus ada perjanjiannya, berapa lama harus dibayarkan, berapa jumlah pembayarannya dan apa sangsinya apabila terjadi keterlambatan atau kekurangan pembayaran dari tagihan piutang yang ada. Pada kenyataannya perusahaan tidak melakukan hal tersebut, sehingga menyebabkan piutang tersebut tidak terjamin kemungkinan pelunasannya. Artinya piutang mempunyai resiko besar kemungkinan tidak tertagih. Sebagai bentuk kehatih-atian akuntansi dan bentuK antisipasi resiko kerugian piutang yang tidak tertagih, maka dalam pembukuan perkiraan piutang usaha selalu diikuti dengan perkiraan kontranya, yaitu rekening penyisihan piutang ragu-ragu atau rekening cadangan kerugian piutang usaha yang berfungsi mengeliminir resiko piutang yang tidak tertagih membebani performa keuangan perusahaan yang tergambar dalam laporan keuangannya. Hal ini sesuai dengan standar yang dikeluarkan oleh Ikatan Akuntan Indonesia yang menyatakan: "Piutang dinyatakan sejumlah bruto tagihan dan dikurangi dengan taksiran jumlah yang tidak tertagih", PSAK, IAI (2015:9.4).

Piutang sebagai salah satu unsur penting dalam neraca yang mempunyai peranan penting bagi perusahaan, yang timbul sebagai akibat adanya kebijakan penjualan kredit. Perlunya pencatatan dan penyajian piutang yang tepat dan sesuai dengan konsep akuntansi keuangan agar menggambarkan keadaan piutang yang seharusnya dapat ditagih yaitu nilai yang dilaporkan dalan neraca sebesar yang terjadi dikurangi yang tidak tertagih.

CV. Linggar Perdana Banjarmasin merupakan perusahaan perdagangan komputer dan aksesoris. Kegiatan transaksi tersebut kebanyakan dilakukan secara kredit. Kredit yang diberikan biasanya paling lama 6 bulan dan paling sedikit satu minggu, tergantung dari kepercayaan atau berapa lama sudah perusahaan berhubungan dengan pembeli tersebut. Tidak ada perjanjian secara legal yang ada hanya kepercayaan antara perusahaan dengan pembeli barang dagangan tersebut, termasuk dalam hal pembayaran tagihan piutang.

CV. Linggar Perdana Banjarmasin melakukan transaksi penjualan dengan sistem penjualan kredit sehingga transaksi tersebut akan menimbulkan piutang bagi perusahaan. Penjualan dari perusahaan saat ini banyak dilakukan secara kredit sehingga ada tenggang waktu sejak penyerahan barang dan jasa sampai saat diterimanya uang sehingga dalam tenggang waktu tersebut penjual mempunyai tagihan kepada pembeli. Dari aktivitas prosedur perusahaan tersebut, penulis menemukan ada customer yang tidak membayar tagihan sesuai dengan jangka waktu yang telah ditentukan. Kemacetan pembayaran piutang tersebut akan menghambat pengelolaan piutang. Piutang macet yang semakin menumpuk akan dapat mengakibatkan kerugian piutang. Dalam penyajian nilai piutang di Neraca perusahaan juga tidak menggunakan nilai bersih (realizable value).

Pengaruhnya terhadap neraca adalah piutang dagang yang disajikan tersebut belum menunjukkan nilai yang wajar dan benar karena nilainya menjadi terlalu besar padahal banyak nilai piutang usaha yang sudah berumur bertahun-tahun belum dilunasi pelanggan. Sementara itu, pengaruhnya terhadap laporan 
laba rugi adalah belum diterapkannya dengan tepat prinsip matching antara pendapatan dan biaya-biaya yang terjadi dalam periode yang bersangkutan karena ada potensi biaya yang tidak terantisipasi sesuai periode yang bersangkutan. Akibat lainnya adalah apabila ternyata terdapat keyakinan bahwa suatu nilai piutang tidak dapat tertagih karena pelanggan yang bermampu lagi melunasi piutangnya, maka yang dibebani adalah laporan laba/rugi yang terakhir padahal mungkin saja piutang yang dihapus tersebut adalah piutang pada periode yang lalu-lalu, selain itu akan ada kemungkinan pembebanan kerugian piutang usaha yang tidak tertagih menjadi terlalu besar dan membebani laporan laba/rugi yang bersangkutan.

Adanya kerancuan informasi ini, akan berpengaruh terhadap pengambilan keputusan pihak manajemen yang menggunakan informasi laporan keuangan untuk pengembangan usaha dan juga bagi pemakai laporan keuangannya. Bila informasi yang disampaikan kemungkinan tidak benar, maka ada kemungkinan keputusan yang dihasilkan menjadi kurang tepat sehingga berakibat terhadap kelangsungan usaha perusahaan.

\section{Studi Literatur}

Menurut Belkaoui (2016:50) yaitu "Akuntansi didefinisikan sebagai suatu aktivitas jasa. fungsinya adalah untuk memberikan informasi kuantitatif dari entitas ekonomi, terutama yang bersifat keuangan dan dimaksudkan untuk bermanfaat dalam pengambilan keputusan ekonomi dan dalam menentukan pilihan di antara serangkaian tindakan-tindakan alternatif yang ada".

Piutang merupakan salah satu elemen aktiva lancar, yang merupakan unsur modal kerja dari suatu perusahaan akibat dilaksanakannya penjualan secara kredit, baik berupa barangbarang atau jasa. Perusahaan pun berhak atas penerimaan kas dimasa yang akan datang baik berupa uang, barang maupun jasa. Piutang usaha ada karena dimulai dari pengambilan keputusan untuk memberikan kredit kepada konsumen, malakukan pengiriman barang, penagihan, dan akhirnya menerima pembayaran dimana hal tersebut ditentukan oleh persyaratan yang telah disepakati bersama pada saat melakukan transaksi.

Menurut Baridwan (2014 : 124) : "piutang adalah "tagihan yang timbul disebabkan oleh penjualan barang-barang atau jasa-jasa yang dihasilkan oleh perusahaan, yang mana ada tenggang waktu dari penyerahan barang dan jasa sampai diterimanya uang. Dalam tenggang waktu tersebut penjual mempunyai tagihan kepada pembeli, biasanya piutang akan dilunasi dalam jangka waktu kurang dari satu tahun".

Klasifikasi piutang untuk tujuan laporan pelaporan keuangan dibagi menjadi dua yaitu sebagai berikut :

1. Piutang lancar atau piutang jangka pendek

Piutang yang diharapkan akan tertagih atau diterima pelunasannya dalam jangka waktu satu tahum atau selama siklus kegiatan normal perusahaan.

2. Piutang tidak lancar atau piutang jangka panjang.

Piutang yang akan tertagih atau jangka waktu pelunasannya lebih dari satu tahun atau dalam periode siklus kegiatan normal perusahaan.

Klasifikasi piutang menurut sumber atau asal terjadinya piutang :

1. Piutang Usaha

Piutang yang timbul dari penjualan barang dan jasa yang dihasilkan perusahaan. Dalam kegiatan normal perusahaan, piutang usaha biasanya akan dilunasi dalam tempo kurang dari satu tahun, oleh karena itu piutang usaha dikelompokan ke dalam aktiva lancar. Piutang ini dibagi menjadi dua, yaitu:

a. Piutang Usaha atau Piutang Dagang.

Piutang usaha adalah janji lisan dari pembeli untuk melakukan pembayaran atas barang yang telah dijual dan jasa yang diberikan yang timbul dari piutang barang atau jasa yang merupakan usaha pokok entitas. Piutang usaha biasanya diperkirakan akan dapat ditagih dalam jangka waktu yang relative pendek, 
biasanya dalam waktu 30 hari hingga 60 hari. Piutang usaha diklasifikasikan dalam neraca sebagai aktiva lancar.

b. Wesel Tagih

Pemberian kredit kepada pelanggan dapat didukung oleh suatu dokumen kredit yang resmi disebut wesel atau promes (promes promossissory note). Wesel tagih adalah perusahaan kepada pembuat wesel janji tertulis untuk membayar sejumlah uang usaha pada tanggal yang telah ditentukan dan tagihan perusahaan kepada pembuat wesel. Pinjaman yang diberikan bias berupa kontrak pinjaman jangka panjang atau jangka pendek (lancar). Wesel biasanya digunakan untuk periode kredit lebih dari 60 hari, seperti dalam penjualan peralatan dalam sistem pencicilan dan untuk transaksi yang menyangkut jumlah nilai yang cukup besar. Sepanjang wesel tagih diperkirakan akan tertagih dalam waktu setahun, maka biasanya diklasifikasikan dalam neraca sebagai aktiva lancar.

2. Piutang Bukan Usaha atau Piutang LainLain.

Piutang bukan usaha merupakan piutang yang timbul karena transaksi penjualan dan sering juga disebut piutang lain-lain. Piutang lain-lain pada umumnya diklasifikasikan dan dilaporkan secara terpisah dalam neraca. Jika piutang ini diharapkan akan tertagih dalam waktu satu tahun, maka piutang tersebut diklasifikasikan sebagai aktiva lancar. Jika piutang tidak dapat ditagih lebih dari satu tahun, maka piutang diklasifikasikan sebagai aktiva tidak lancar. Piutang ini meliputi tuntunan atas suatu kerugian, setoran yang dibayarkan sebagai jaminan, piutang deviden, piutang bunga, piutang pajak, dan piutang dari karyawan perusahaan.

Akutansi piutang adalah sistem, prosedur dan proses mengidentifikasikan dan mengukur dalam pencatatan piutang yang dilakukan oleh setiap perusahaan dan dilakukan menurut siklus akutansi yang biasanya dilakukan yaitu dalam model jurnal dan posting setelah ada bukti atau dokumen sah yang dinyatakan bahwa transaksi itu telah terjadi.

Pengakuan piutang adalah jumlah yang harus diakui dari harga pertukaran diantara kedua belah pihak. Pengakuan piutang dagang tersebut dapat berbeda bila terjadi retur atau potongan penjualan dan potongan tunai penjualan.

Piutang dagang disajikan dineraca sebesar nilai realisasi bersihnya, yaitu jumlah piutang bruto dikurangi dengan taksiran jumlah piutang yang tidak tertagih. Jumlah piutang yang tidak tertagih sering disebut kerugian piutang. Hal ini wajar didalam dunia usaha, apalagi bila penjualan dilakukan secara kredit (Sigit Hermawan, dkk, 2018 : 26)

Menurut Prinsip Akutansi Indonesia piutang dagang harus dicatat dan dilaporkan dalam neraca sebesar nilai kas bersih (neto) yang bias direalisasikan yaitu jumlah piutang setelah dikurangi Cadangan Kerugian Piutang Tidak Tertagih.

Menurut Riyanto (2015： 80) : penilaian risiko dapat dipertimbangkan hal-hal sebagai berikut :

1. Character (Karakter pribadi), menggambarkan besarnya probilitas bahwa langganan yang bersangkutan akan memenuhi kewajibannya. Bagian kredit yang berpengalaman umumnya menekankan faktor moral tersebut sebagai segi terpenting dalam penilaian suatu kredit

2. Capacity (Kemampuan), merupakan penilaian subjektif atas kemampuan membayar dari langganan. Hal ini diketahui dari prestasi bisnis langganan tersebut di masa lalu, yang disokong oleh hasil penelitian langsung pada toko di samping melihat metode yang digunakan.

3. Capital (modal), yakni diukur melalui posisi keuangan perusahaan sebagaimana dapat dilihat dari analisa ratio keuangan dengan tekanan pada rasio-rario dan jumlah kali perolehan bunga.

4. Colleteral (Jaminan), yakni menggambarkan jumlah aktiva yang 
dijadikan sebagai jaminan oleh calon langganan, akan tetapi hal ini bukanlah merupakan pertimbangan yang sangat penting karena tujuan perusahaan dalam memberikan kredit bukanlah menyita kemudian menjual aktiva langganan.

5. Condition (kondisi perekonomian), yakni gambaran dampak trends perekonomian umum atas daerah atau tempat yang mungkin mempengaruhi kemampuan langganan untuk memenuhi kewajibannya.

\section{Metode Penelitian}

Jenis Penelitian

Metode yang digunakan dalam penelitian ini adalah analisis data deskriptif kualitatif, dipilihnya metode ini bertujuan untuk memberikan gambaran yang jelas, sistematis, dan aktual tentang analisis akuntansi piutang pada CV. Linggar Perdana Banjarmasin yang seharusnya.

Jenis Data

Data kualitatif adalah data yang tidak diwujudkan dengan angka-angka melainkan dalam bentuk yang mengambarkan keadaan dan peristiwa tertentu berupa data piutang.

\section{Sumber Data}

1. Data primer adalah data yang diperoleh langsung dari objek yang diteliti. Hal ini dilakukan dengan praktek di lapangan.

2. Data sekunder adalah data yang diperoleh dari perusahaan yang bersangkutan yaitu sejarah singkat perusahaan, struktur organisasi dan data-data lain yang mendukung penelitian ini.

Teknik Pengumpulan Data

1. Library Research (Riset Kepustakaan) yaitu teknik mengumpulkan, meneliti, mempelajari dokumen, catatan dan laporanlaporan yang berhubungan dengan masalah yang akan diteliti dari dokumen-dokumen yang dimiliki oleh perusahaan.

2. Field Research (Riset Lapangan) merupakan studi lapangan dilakukan dengan datang ke objek penelitian untuk melakukan pengamatan dan meminta data yang diperlukan. Data-data tersebut diperoleh dengan cara :

a. Observasi, yaitu data yang diperoleh adalah data yang berkenaan dengan analisis akuntansi piutang.

b. Wawancara, yaitu data yang diperoleh adalah data yang berkenaan dengan analisis akuntansi piutang.

c. Dokumentasi, yaitu data yang diperoleh adalah data piutang.

Teknik Analisis Data

Pengolahan data dilakukan dengan memeriksa kembali data yang telah dikumpulkan, analisa data secara deskriptif kualitatif yakni dengan membandingkan data yang diperoleh di perusahaan yang menjadi objek penelitian dengan teori-teori akuntansi yang relevan dengan masalah yang dibahas.

\section{Hasil Penelitian dan Pembahasan}

Cara menentukan persentase piutang untuk masing-masing umur piutang adalah dengan meneliti debitur yang memiliki tunggakan pembayaran berdasarkan lamanya piutang. Setelah piutang dikelompokkan berdasarkan umur masing-masing, maka langkah selanjutnya adalah menentukan taksiran kerugian piutang untuk masing-masing umur piutang tersebut. Untuk itu dianjurkan agar piutang usaha digolongkan menjadi :

1. Belum jatuh tempo,

2. Menunggak 1-30 hari,

3. Menunggak $31-90$ hari,

4. Menunggak 91-180 hari,

5. Menunggak 180-360 hari, dan

6. Menunggak > 360 hari.

Setelah itu, langkah selanjutnya adalah menentukan persentasi kerugian piutang untuk masing-masing umur piutang.

Tabel 1. Persentase Tidak Tertagihnya Piutang Usaha

\begin{tabular}{|c|l|c|}
\hline \multirow{2}{*}{ Periode } & \multicolumn{1}{|c|}{$\begin{array}{c}\text { Kelompok } \\
\text { Umur }\end{array}$} & CKP \\
\hline \multirow{3}{*}{2017} & Belum jatuh tempo & $0 \%$ \\
\cline { 2 - 3 } & Menunggak 7 s/d 14 hari & $5 \%$ \\
\cline { 2 - 3 } & Menunggak 15 s/d 30 hari & $10 \%$ \\
\hline
\end{tabular}

JIEB, Jilid 6, No 2, Juli 202 ISSN Online 2615-2134 


\begin{tabular}{|l|l|c|}
\hline \multirow{1}{*}{} & Menunggak 31 s/d 90 hari & $20 \%$ \\
\cline { 2 - 3 } & Menunggak 91 s/d 180 hari & $30 \%$ \\
\cline { 2 - 3 } & Menunggak lebih dari 1 tahun & $50 \%$ \\
\cline { 2 - 3 } & Jumlah Piutang tahun 2017 & $\mathbf{1 0 0 \%}$ \\
\hline \multirow{5}{*}{2018} & Belum jatuh tempo & $0 \%$ \\
\cline { 2 - 3 } & Menunggak 7 s/d 14 hari & $5 \%$ \\
\cline { 2 - 3 } & Menunggak 15 s/d 30 hari & $10 \%$ \\
\cline { 2 - 3 } & Menunggak 31 s/d 90 hari & $20 \%$ \\
\cline { 2 - 3 } & Menunggak 91 s/d 180 hari & $30 \%$ \\
\cline { 2 - 3 } & Menunggak lebih dari 1 tahun & $50 \%$ \\
\cline { 2 - 3 } & Jumlah Piutang tahun 2018 & $\mathbf{1 0 0 \%}$ \\
\hline \multirow{5}{*}{2018} & Belum jatuh tempo & $0 \%$ \\
\cline { 2 - 3 } & Menunggak 7 s/d 14 hari & $5 \%$ \\
\cline { 2 - 3 } & Menunggak 15 s/d 30 hari & $10 \%$ \\
\cline { 2 - 3 } & Menunggak 31 s/d 90 hari & $20 \%$ \\
\cline { 2 - 3 } & Menunggak 91 s/d 180 hari & $30 \%$ \\
\cline { 2 - 3 } & Menunggak lebih dari 1 tahun & $50 \%$ \\
\cline { 2 - 3 } & Jumlah Piutang tahun 2019 & $\mathbf{1 0 0 \%}$ \\
\hline
\end{tabular}

Sumber : Data Diolah

Penilaian piutang yang seharusnya dapat dilakukan oleh CV. Linggar Perdana Banjarmasin berdasarkan analisa daftar umur piutang. Berikut perhitungan persentase taksiran kerugian piutang yang disajikan berdasarkan daftar analisa umur piutang $\mathrm{CV}$. Linggar Perdana Banjarmasin pada tahun 20172019:

Tabel 2. Estimasi Tak Tertagihnya Piutang Berdasarkan Daftar Analisa Umur Piutang Periode Tahun 2017 (Dalam Rupiah)

\begin{tabular}{|c|c|c|c|c|}
\hline Periode & $\begin{array}{c}\text { Kelompok } \\
\text { Umur }\end{array}$ & $\begin{array}{c}\text { Saldo } \\
\text { Piutang }\end{array}$ & $\begin{array}{c}\text { Nilai } \\
\text { Estimasi }\end{array}$ & Jumlah \\
\hline \multirow{8}{*}{2017} & Belum jatuh tempo & 33.843 .750 , & $0 \%$ & \\
\hline & $\begin{array}{l}\text { Telah jatuh tempo 1-30 } \\
\text { hari }\end{array}$ & 225.032.438, & $5 \%$ & 11.251.622,- \\
\hline & $\begin{array}{l}\text { Telah jatuh tempo 31-60 } \\
\text { hari }\end{array}$ & 38.000.000, & $10 \%$ & $3.800 .000,-$ \\
\hline & $\begin{array}{l}\text { Telah jatuh tempo 61-90 } \\
\text { hari }\end{array}$ & 174.932.406, & $20 \%$ & $34.986 .481,--$ \\
\hline & $\begin{array}{l}\begin{array}{l}\text { Telah jatuh tempo 91-180 } \\
\text { hari }\end{array} \\
\end{array}$ & 116.505 .625 & $30 \%$ & $34.951 .688,-$ \\
\hline & $\begin{array}{l}\text { Telah jatuh tempo 181-365 } \\
\text { hari }\end{array}$ & 5.435 .781$. & $50 \%$ & $2.717 .891,-$ \\
\hline & Diatas 365 hari & & $80 \%$ & \\
\hline & Jumlah Piutang tahun 2017 & 593.750 .000 & $\begin{array}{l}\text { Total } \\
\text { estimasi }\end{array}$ & 87.707.681,-- \\
\hline
\end{tabular}

Sumber : Data Diolah

Berdasarkan dari daftar analisa umur piutang, dapat diketahui perhitungan perkiraan tidak tertagihnya piutang pada periode 2017 sebesar Rp. 87.707.681,-. Dari tabel diatas, pencatatan jurnal penyesuaian kerugian piutang Sur sebesar Rp. 45.648.727 tersebut dapat dilakukan dengan asumsi pembukuan belum tutup, yaitu sebagai berikut.

Beban Kerugian Piutang Rp. 87.707.681,-

Cadangan Kerugian Piutang Rp. 87.707.681,-
Tabel 3. Estimasi Tak Tertagihnya Piutang Berdasarkan Daftar Analisa Umur Piutang Periode Tahun 2018 (Dalam Rupiah)

\begin{tabular}{|c|c|c|c|c|}
\hline Periode & $\begin{array}{c}\text { Kelompok } \\
\text { Umur }\end{array}$ & $\begin{array}{c}\text { Saldo } \\
\text { Piutang }\end{array}$ & $\begin{array}{c}\text { Nilai } \\
\text { Estimasi }\end{array}$ & Jumlah \\
\hline \multirow{8}{*}{2018} & Belum jatuh tempo & & & \\
\hline & $\begin{array}{l}\text { Telah jatuh tempo 1-30 } \\
\text { hari }\end{array}$ & \begin{tabular}{|l}
21.908 .735 \\
322.888 .998
\end{tabular} & $0 \%$ & 16.144 .450 \\
\hline & $\begin{array}{l}\text { Telah jatuh tempo 31-60 } \\
\text { hari }\end{array}$ & 60.017 .100 & $10 \%$ & 6.001 .710 \\
\hline & $\begin{array}{l}\text { Telah jatuh tempo 61-90 } \\
\text { hari }\end{array}$ & 163.824 .106 & $20 \%$ & 32.764 .821 \\
\hline & $\begin{array}{l}\text { Telah jatuh tempo 91-180 } \\
\text { hari }\end{array}$ & 181.436 .310 & $30 \%$ & 54.430 .893 \\
\hline & $\begin{array}{l}\text { Telah jatuh tempo 181-365 } \\
\text { hari }\end{array}$ & 19.374 .751 & $50 \%$ & 9.687 .376 \\
\hline & Diatas 365 hari & & $80 \%$ & (2) \\
\hline & Jumlah Piutang tahun 2018 & 769.450 .000 & $\begin{array}{l}\text { Total } \\
\text { estimasi }\end{array}$ & 119.029 .250 \\
\hline
\end{tabular}

Sumber : Data Diolah

Berdasarkan dari daftar analisa umur piutang, dapat diketahui perhitungan perkiraan tidak tertagihnya piutang pada periode 2018 sebesar Rp. 119.029.250,-. Dari tabel 3, pencatatan jurnal penyesuaian kerugian piutang sebesar Rp. 119.029.250,- tersebut dapat dilakukan dengan asumsi pembukuan belum tutup, yaitu sebagai berikut.

Beban Kerugian Piutang Rp. 119.029.250,-

Cadangan Kerugian Piutang Rp. 119.029.250,-

Tabel 4. Estimasi Tak Tertagihnya Piutang Berdasarkan Daftar Analisa Umur Piutang Periode Tahun 2019 (Dalam Rupiah)

\begin{tabular}{|c|c|c|c|c|}
\hline Periode & $\begin{array}{l}\text { Kelompok } \\
\text { Umur }\end{array}$ & $\begin{array}{l}\text { Saldo } \\
\text { Piutang }\end{array}$ & $\begin{array}{c}\text { Nilai } \\
\text { Estimasi }\end{array}$ & Jumlah \\
\hline \multirow{6}{*}{2019} & Belum jatuh tempo & 22.499 .330 & $0 \%$ & \\
\hline & Telah jatuh tempo 1-30 hari & 335.394 .109 & $5 \%$ & 16.769 .705 \\
\hline & $\begin{array}{l}\text { Telah jatuh tempo } 31-60 \\
\text { hari }\end{array}$ & 172.431 .840 & $10 \%$ & 17.243 .184 \\
\hline & $\begin{array}{l}\text { Telah jatuh tempo 61-90 } \\
\text { hari }\end{array}$ & 344.596 .146 & $20 \%$ & 68.919 .229 \\
\hline & $\begin{array}{l}\text { Telah jatuh tempo 91-180 } \\
\text { hari }\end{array}$ & 70.428 .575 & $30 \%$ & 21.128 .573 \\
\hline & Jumlah Piutang tahun 2019 & 945.350 .0 & \begin{tabular}{|l} 
Total \\
estimasi
\end{tabular} & 124.060 .691 \\
\hline
\end{tabular}

Sumber : Data Diolah

Berdasarkan dari daftar analisa umur piutang, dapat diketahui perhitungan perkiraan tidak tertagihnya piutang pada periode 2019 sebesar Rp. 124.060.691,-. Dari tabel 4, pencatatan jurnal penyesuaian kerugian piutang sebesar Rp. 124.060.691,- tersebut dapat 
dilakukan dengan asumsi pembukuan belum tutup, yaitu sebagai berikut.

Beban Kerugian Piutang Rp. 124.060.691,Cadangan Kerugian Piutang Rp. 124.060.691,-

Setelah adanya perubahan yang terjadi tersebut terlihat penurunan nilai piutang perusahaan yang disebabkan oleh adanya pengurangan dari cadangan kerugian piutang. Akibat adanya pembebanan biaya kerugian piutang tersebut laba yang disajikan perusahaan yang dulunya tinggi akan turun. Pencatatan yang dilakukan terhadap timbulnya perkiraan dapat dilakukan saat tutup buku yaitu sebagai berikut.

Tahun 2017

Cadangan Kerugian Piutang Beban Kerugian Piutang

Tahun 2018

Cadangan Kerugian Piutang Beban Kerugian Piutang

Tahun 2019

Cadangan Kerugian Piutang

Beban Kerugian Piutang

Rp . 87.707.681,Rp. 87.707.681,-

Rp . 119.029.250,Rp. 119.029.250,-

Rp . 124.060.691,Rp. 124.060.691,-

Dampak perubahan tersebut terhadap laba yaitu sebagai berikut.

Tahun 2017

\begin{tabular}{|c|c|c|c|}
\hline $\begin{array}{l}\text { Penyesuaia } \\
\mathrm{n}\end{array}$ & $\begin{array}{l}87.707 .681,- \\
593.750 .000, \\
-\end{array}$ & & $\begin{array}{l}506.042 .319, \\
-\end{array}$ \\
\hline Saldo & 506.042.319, & $\begin{array}{l}\text { Sald } \\
\text { o }\end{array}$ & $\begin{array}{l}506.042 .319, \\
-\end{array}$ \\
\hline
\end{tabular}

Tahun 2018

\begin{tabular}{ll|ll}
\hline Penyesuaia & 119.029 .250$, & & 650.420 .750$, \\
$\mathrm{n}$ & - & & - \\
& 769.450 .000$, & & \\
Saldo & - & Sald & 650.420 .750$, \\
& 650.420 .750$, & o & -
\end{tabular}

Tahun 2019

\begin{tabular}{|c|c|c|c|}
\hline $\begin{array}{l}\text { Penyesuaia } \\
n\end{array}$ & $\begin{array}{l}124.060 .691, \\
- \\
945.350 .000, \\
-\end{array}$ & & $\begin{array}{l}821.289 .308, \\
-\end{array}$ \\
\hline Saldo & $\begin{array}{l}\text { 821.289.308, } \\
-\end{array}$ & $\begin{array}{l}\text { Sald } \\
0\end{array}$ & $\begin{array}{l}821.289 .308, \\
-\end{array}$ \\
\hline
\end{tabular}

Jadi, penurunan jumlah modal per 20172019 ini mengakibatkan posisi neraca menjadi kembali seimbang. Hal ini dikarenakan penurunan jumlah modal yang sama besarnya dengan penurunan jumlah piutang, sehingga penurunan total aktiva dan pasiva adalah sama. Perlakuan akuntansi piutang ini perlu diperhatikan oleh pihak perusahaan, agar penyajian laporan keuangan sesuai dengan SAK. Sementara itu, piutang tak tertagih dapat berpengaruh sangat besar terhadap kewajaran laba yang telah dilakukan dalam perhitungan laba rugi yang disajikan periode tahun 20172019. Laba yang dilaporkan pihak perusahaan terlalu besar dari laba yang seharusnya. Oleh sebab itu, dengan diterapkan beban kerugian piutang tersebut, maka akan dihasilkan informasi keuangan yang wajar dan akurat. Jadi, dapat dikatakan bahwa laporan keuangan yang disajikan oleh pihak perusahaan belum memenuhi syarat kelengkapan penyajian informasi keuangan. Selain itu, laporan keuangan yang disajikan tidak memenuhi kriteria dari prinsip kehati-hatian yang didasari oleh pertimba-ngan yang sehat dalam menghadapi ketidakpastian peristiwa ekonomi di masa yang akan datang. Perlakuan akuntansi piutang yang sesuai dengan Standar Akuntansi Keuangan No. 09 Tahun 2015 berpengaruh terhadap kewajaran, validitas, dan keakuratan informasi keuangan perusahaan. Peneliti menyarankan agar CV. Linggar Perdana Banjarmasin segera mengadakan perubahan terhadap perlakuan piutang, dengan cara menyajikan piutang sebesar jumlah bruto yang dikurangi dengan taksiran jumlah piutang tak tertagih. Untuk itu, perusahaan perlu membuat perkiraan cadangan kerugian piutang sebagai rekening lawan (pengurang) piutang perusahaan dalam neraca.

\section{Penutup}

1. Analisis perlakuan akuntansi piutang usaha yang diterapkan CV. Linggar Perdana Banjarmasin tidak mengacu pada Standar Akuntansi Keuangan No. 09 Tahun 2015 yang mengharuskan penyajian piutang sebesar jumlah bruto dikurangi taksiran jumlah yang tidak dapat diterima. Akibatnya, laporan yang disusun perusahaan tidak mencerminkan keadaan keuangan dan hasil usaha seharusnya.

2. Akuntansi piutang usaha CV. Linggar Perdana Banjarmasin yang seharusnya 
menggunakan metode cadangan dalam menyusun laporan keuangan perusahaan yang sesuai dengan Standar Akuntansi Keuangan No. 09 Tahun 2015 untuk memprediksi besarnya jumlah piutang yang tak tertagih yang akan diakui sebagai kerugian piutang perusahaan.

Berdasarkan hasil analisis dan kesimpulan, maka penulis mencoba untuk memberikan saran masukan kepada CV. Linggar Perdana Banjarmasin sebagai berikut:

1. Agar laporan keuangan menghasilkan informasi keuangan yang wajar dan andal, maka perlakuan akuntansi yang dijalankan hendaknya disesuaikan dengan Standar Akuntansi Keuangan No. 09 Tahun 2015. Selain itu, perusahaan hendaknya melakukan perubahan perlakuan akuntansi piutang usaha, sehingga piutang yang disajikan dalam neraca dapat menunjukkan nilai bersih yang dapat direalisasikan.

2. Untuk penyesuaian pencatatan akuntansi piutang, hendaknya perusahaan membentuk cadangan kerugian piutang yang berfungsi untuk meminimalkan piutang yang tidak dapat diterima. Untuk menentukan besarnya kerugian piutang, sebaiknya perusahaan menggunakan analisis umur piutang.

\section{Daftar Pustaka}

Belkaoui, Ahmad. 2016. Intermediate Accounting, Edisi Kedelapan. Yogyakarta: BPFE.

Dwi, Indra. 2017. Akuntansi Keuangan. Yogyakarta: Erlangga Buku satu. Yogyakarta: Penerbit AMP YKPN.

Harnanto. 2016. Akuntansi Keuangan Menengah, Buku Satu. Yogyakarta: BPFE.

IAI. 2015. Standar Akuntansi Keuangan. Jakarta: Salemba Empat.

Halim, Muhammad. 2015. Akuntansi Intermedite, Ikhtiar Teori \& Soal Jawab. Yogyakarta: BPFE

Haryono, Jusup, 2015. Dasar-Dasar Akuntansi Jilid 1. Yogyakarta: Sekolah Tinggi Ilmu Ekonomi.
2016. Dasar-Dasar

Akuntansi, Edisi Keenam.

Kieso, Donald E., Weygandt, Jerry J.,\& Warfield, Terry D. 2017. Intermediate Accounting Twelfth Edition. New Jersey: John Wiley \& Sons (Asia) Pte. Ltd.

Muawanah. 2015, Prinsip, Dasar dan Konsep : Akuntansi Menengah, YKPN, Yogyakarta

Munandar, Asep. 2016. Prinsip dan Kaidah : Pengantar Akuntansi, Grafindo, Jakarta

Niswonger. 2016, Pengantar Akuntansi. Jakarta: Erlangga.

Reeve dan Warren. 2016. Prinsip-prinsip Akuntansi. Jilid Kelima. (Terjemahan). Jakarta: Erlangga.

Riyanto, Bambang, 2015. Dasar-dasar Manajemen Keuangan. Jakarta: Salemba Empat.

Sugiri, Slamet, \& Sumiyana. 2015. Akuntansi Keuangan Menengah. Yogyakarta: Penerbit STIE YKPN.

Susilowati, Lantif, 2016. Akuntansi Keuangan Menengah, Edisi Revisi. Yogyakarta: AMP YKPN.

Soemarso. 2017. Akuntansi Pengantar. Yogyakarta: AMP YKPN.

Soetedjo. Soegeng. 2017. Akuntansi Intermediate. Surabaya: Airlangga University Press.

Umar, Husein. 2015. Riset Akuntansi. Jakarta: PT Gramedia. 